\title{
A study on relationship between financial performance and supply chain in the accepted companies in Borsa Istanbul
}

\author{
H. Şaduman Okumuşa ${ }^{a}$, Shahryar Ghorbani ${ }^{b^{*}}$ and Serpil Karatepe ${ }^{b}$
}

\begin{abstract}
aProf.Dr.H.Saduman Okumus, Department of International Trading and Finance, Faculty of Economic, Management and Social Sciences, Istanbul Gedik University, Turkey

${ }^{b}$ Phd Student in Management and Business Administration Programme, Graduate School of Social Sciences, Istanbul Gedik University, Turkey

\begin{tabular}{l}
\hline C H R O N I C L E \\
\hline Article history: \\
Received October 11, 2018 \\
Accepted December 122018 \\
Available online \\
December 142018 \\
\hline Keywords: \\
Supply Chain Management \\
Financial Success \\
SCOR Model \\
Value Creation
\end{tabular}

\section{A B S T R A C T}

The lack of a proper communication link between supply chain operations and financial performance seems to be due to the difficulty of using the operational metrics of supply chain measurement to reach the financial goals. This study is an attempt to find the effect of supply chain management (SCM) implementation on the financial success of the firms. The study considers the effects of Revenue, Prime Cost, Cash-to-cash cycle period and Return on working capital on the financial performance of the selected firms listed in Istanbul stock exchange from 2012 to 2017. The study divides the sample size based on their financial growth into two groups and using some statistical test measures the difference between two groups, statistically. The results show that there was a significant difference between the mean of high-growth and lowgrowth companies in terms of SCM implementation. However, the effects of cost, cash cycle and working capital on financial performance were not confirmed.
\end{abstract}

(C) 2019 by the authors; licensee Growing Science, Canada

\section{Introduction}

Nowadays, competition among business units is based on the production of goods and services according to customer needs (Aitken et al., 2003; Broz et al., 2018). In addition to the globalization and escalation of competition in the international arena along with technological advancements, competition has led to the formation of a new business environment to create opportunities for bigger success (Fisher et al., 1997; Ballou et al., 2000). As a result many companies have moved toward the customer process in order to reduce the amount of time taken to meet customer needs as well as providing better interaction with their suppliers to gain competitive advantages, as they realize that in a closed environment they cannot continue to survive (Beamon, 1999). This procedure led to a shift in the direction of companies' view to supply chain processes as a critical activity increasing value creation for customers (Lai et al., 2002). Supply chain management (SCM) consists of different approaches and effectively integrates suppliers, manufacturers, distributors and customers to make long-term performance improvement of individual companies and the whole supply chain in a comprehensive, high-performance business model (Chopra \& Meindl, 2007). Supply chain

\footnotetext{
* Corresponding author

E-mail address: 181220009@stu.gedik.edu.tr (S. Ghorbani) 
management involves the design and management of all procurement and activities, conversion and all procurement management activities as well as coordination and collaboration with existing partners in the network (Holland et al., 2006; Cao \& Zhang, 2011). It also suggests that supply chain management involves dealing with one of the most important differences between supply chain decisions and financial investment outcomes (Huang et al., 2008). Since the cost and quality of service sold directly is associated with the purchase services, supply chain management and its related strategies are very important for the success of any firm (Davis, 2005). Therefore, supply chain policies, such as supplier selection, play a key role on the success of the firms (Hartley \& Choi, 1996; Arifin et al., 2019). Lean practices contribute to the internal processes of any firm, along with the principles of just in time (JIT) from other known methods in SCM (Barge et al., 2006). SCM integrates the internal processes of the firms and the customers form the basis of the whole ideas embedded in SCM. With the widespread application and usage of the Internet, Web-based systems help organizations form a strong type of customer relationship management (CRM) (Scott \& Westbrook, 1991; Frohlich \& Westbrook, 2002; Asiyanbi \& Ishola, 2018).

While interest in implementing SCM procedures and strategies in organizations is increasing, many of the existing knowledge and practices in this field are limited only to financial domains such as purchase, procurement, information technology and marketing but little research has been accomplished in relationship with its operational implementation and financial performance improvement (Gardner \& Lambert, 2006). However, some operational metrics have been developed over time, which links the processes and activities of the supply chain to financial performance. The relationships among all the measures of operational and financial measurements have to be determined (Ellram \& Cooper, 1990). The identification of these criteria helps transform financial objectives into operational criteria, and intermediate managers can use these criteria into their operational activities rather than the organization. On the other hand, knowledge of the effect of processes on operational and financial metrics can be used to enable supply chain performers to evaluate the profitability of the business unit (Ketzenberg et al., 2008). Hence, identifying the relationships between supply chain metrics and firm financial success may fill the gap between the operational and financial perspectives of SCM. In addition, establishing a connection between supply chain management and financial aspect is a necessity to reach success in business development. Thus, in order to develop and implement SCM practices, the need to participate in the company's top management and business units will be felt under its set. While senior financial officials consider the company's financial success as a result of the growth in revenue and profit of each share, effective and efficient use of assets such as cash circulation, capital circulation, or cash from operations maximize the value of shareholders' wealth and SC managers may address issues such as timeliness, equity, and forecasting of reliability and other qualitative materials (Carter \& Liane Easton, 2011).

Today, most senior decision-maker managers have accepted that SCM plays essential role on the success of the organization's operations. From 1997 to 2000, a study by an international research team from the DB Schenker and Stanford universities revealed that the SCM had been critically essential element in about $10 \%$ of the communities investigated. In another study, Kaya and Azaltun (2012), the firms with high supply chain firms represented a better profit, equity returns, and profit margin. Nevertheless, little research has been accomplished on how to influence the impact of SCM practices on the financial success of firms. In this study, we intend to investigate the relationship between SCM practices and the financial success of the company using experimental data. The structure of the paper is that in the second and third section, the theoretical foundations and methodology of the research are studied and then, in the fourth section, the findings are discussed. The fifth section is also devoted to concluding and expressing the results of the research. 


\section{Literature review}

First we define the role of SCM that plays in the financial Success of an organization. The planning, organization and control of activities in the supply chain are called supply chain management (Chen et al., 2015). According to Cooper et al. (1997) "SCM is an integration processes that provides services and information, these result can be creation of added value for customers and other stakeholders. These processes include customer procurement, stock control, and transportation management, such as non traditional procurement activities such as purchase, support from production, packaging, and order of the customer order".

SCM can be seen as a simple of an evolutionary and cumulative innovation, often referred to as originating frominternal programs aimed at improving the overall effectiveness (Saad, 2002). The focus of SCM can increase interests in insider the organization, reduces the non-value-added processes and creates value among all components of the supply chain (New \& Ramsay, 1997). This major emphasis on integration strongly leads to the development of effective and long-term relationships between buyers and suppliers (Spekman, 1991). With the above definitions of SCM, it can be concluded that SCM can be described as the management of allactivities associated with transferring goods from raw materials to the consumer. It involves selection of the resources and supplies, production scheduling, order processing, inventory management, transfer, storage, and customer service (Burgess et al., 2006). The view that stakeholders own the company, which is why the business unit is responsible for them is not a new issue. The value of any business unit can be increased through four different methods: revenue increase, reduced operating costs, reduction of capital in circulation, and increased productivity, for example an initiative with a focus on reducing inventory level may lead to the the sales loss level, and the benefits of this initiative can be easily measurable. However, the long-term growth requires an increase in revenue and managers have to concentrate on all four expressed methods to increase the value of the firm (Lambert et al., 2005). Therefore, attention to stakeholders for managers decision-making is that the same increase in firm value is a positive net present value for future earnings streams by increasing shareholder value (Krause et al., 2009).

The main strategies that arise with regard to increasing shareholder value are three operational, investment and financial strategies. The operational strategy helps improve economic efficiency, reduce operating costs, or through improvement in effective use of resources, leading to improvements in profitability. Investment strategies such as updating at the capacity of production and technological processes lead to overall improvement at the firm's performance level. Financial strategies are called strategies to raise funds through issuance of shares or debts. In this regards paying dividends and restructuring are financial models that corporate managers can use to increase shareholder value, so the adaption of these strategies have to maximize the shareholders' wealth (Thomas et al., 2011). The measurement of financial performance to assess the success of SCM success is very critical. Since it makes it easy to understand behavior, thereby improving competitiveness. However there seems to be a missing link between measuring the daily operations of the supply chain and the financial performance of the missing ring (Dugato et al., 2015).

While many qualitative criteria include measures of customers satisfaction, flexibility, integration of information and materials, effective risk management and supplier performance, other metrics such as inventory circulation, profit Margin and cash to cash circulation are easily obtained (Otto \& Kotzab, 2003). Identifying the implications of stakeholder's value in order to make decision about procurement category and the importance of the expected return has always been an implicit concept among financial goals (Pettit et al., 2010). In the supply chain study using the measurement of company products, services, process and comparing them with successful benchmark companies is a relevant concept (Christopher, 1998). Previous studies on the benchmark chain has shown that as the managers compare their practices on competing firms, this may lead to increase productivity in the supply chain. Gradually, the benchmark has become the best way of analysis because of the combination of quantitative metrics with qualitative procedures. Such a model allows managers to talk more 
confidently about issues such as whether they are favorable or not to change the organization's business performance, improve the predictable performance, achieve and measure it (Stewart, 1997).

\section{Research methodology}

This section explores the introduction of methodology, including the extension of hypotheses, selecting criteria, statistical sample, data collection, and data analysis techniques.

\subsection{Research hypotheses}

The supply chain management framework in this study states that SCM practices have a direct impact on the financial success of the firms. The SCM practices are expected to increase the financial success of a firm through its total capital market value. It is defined financially that it can increase the growth rate of the market value of its assets, which is the fundamental purpose of maximizing shareholders' value. In this study, we are looking to answers the following questions:

$\mathrm{R}_{1}$ : Is there any relationship between companies with better supply chain management and financial success?

To answer this question, the following assumptions are set:

$\mathrm{H}_{1}$ : There is a significant difference between financial success of the firms with high sales growth and low sales growth.

$\mathrm{H}_{2}$ : There is a significant difference between financial success of the firms with high cost and low cost.

$\mathrm{H}_{3}$ : There is a significant difference between financial success of firms with shorter cash flow recycling cycle and companies with a higher cash recycling cycle.

$\mathrm{H}_{4}$ : There is a significant difference between financial success of firms with high productivity rates and firms with low productivity rates.

Then, in the next section, we examine the following question:

$\mathrm{R}_{2}$ : Which of the four SCM criteria has a greater impact on financial success?

In order to identify this, the following hypothesis is stated:

$\mathrm{H}_{5}$ : Investors consider the supply chain components in their assessment when evaluating the stock.

To measure this hypothesis, the following regression model is used:

$$
Y_{i}=\beta_{0}+\beta_{1} x_{1 i}+\beta_{2} x_{2 i}+\beta_{3} x_{3 i}+\beta_{4} x_{4 i}+\varepsilon_{i},
$$

where $Y_{i}$ (Financial success) represents the dependent variable, $x_{1 i}$ to $x_{4 i}$ represent the independent variables, $\beta_{0}$ to $\beta_{4}$ are coefficients to be estimated and $\varepsilon_{i}$ denotes the residuals. The independent variables include Revenue $\left(X_{1}\right)$, which is an index for the reliability, accountability and flexibility in SCM. $X_{2}$ represents Prime Cost as a percentage of revenue, which is also as an index for cost attribute in SCM. $X_{3}$ denotes the time of the cash-to-cash cycle period which is an index for the management of the assets of SCM assets. Finally, $\mathrm{X}_{4}$ represents the return on working capital, which is an index for the assets management attribution to SCM. 


\subsection{Selection criteria}

The most important benefits of the Supply Chain Operation Reference (SCOR) model is that the standard processes provide definitions for the relationship between processes, performance metrics and set standards (Chan et al., 2003). This framework can be effectively used by financial managers to convert financial goals into operational metrics so that middle managers can be able to use these criteria into operational activities rather than the organization. This framework can help supply chain managers in knowledge of the impact of processes on operational and financial metrics in order to assess the operational and financial effects of the changes being carried out within the organization. It tries to link operational metrics to the value of shareholders (Tang \& Tomlin, 2008). The SCOR model consists of three levels (See Table 1).

\section{Table 1}

Linking SCOR model performance metrics to the financial performance factors

\begin{tabular}{|c|c|c|c|c|c|c|}
\hline \multirow[b]{3}{*}{ SCOR Level 1} & \multicolumn{5}{|c|}{ Increasing the return of the capital } & \multirow{3}{*}{$\begin{array}{l}\text { EVA } \\
\text { Component }\end{array}$} \\
\hline & \multicolumn{3}{|c|}{ Customer-Facing } & \multicolumn{2}{|c|}{ Internal-Facing } & \\
\hline & Reliability & Responsibility & Flexibility & Cost & Assets & \\
\hline Perfect Order Fulfillment & $\sqrt{ }$ & & & & & Revenue \\
\hline Order Fulfillment Cycle Time & & $\sqrt{ }$ & & & & \\
\hline Upside Supply Chain Flexibility & & & $\sqrt{ }$ & & & \\
\hline Upside Supply Chain Adaptability & & & $\sqrt{ }$ & & & \\
\hline Downside Supply Chain Adaptability & & & $\sqrt{ }$ & & & Cost \\
\hline Supply Chain Management Cost & & & & $\sqrt{ }$ & & \\
\hline Cost of Goods Sold & & & & $\sqrt{ }$ & & \\
\hline Cash-to-Cash Cycle time & & & & & $\sqrt{ }$ & \\
\hline Return on Supply Chain Fixed Assets & & & & & $\sqrt{ }$ & Assets \\
\hline Return on Working Capital & & & & & $\sqrt{ }$ & \\
\hline
\end{tabular}

First Level defines the range and content of the supply chain using five basic level processes (plan, resource, construction, delivery and return). At the second level, the supply chain configuration is determined by using a bundle of processes. Processes are aligned with operational strategies at this stage. At the third level, the flow diagram is defined by using elements of the process or specific tasks of each previous level processes (Reddy et al., 2008). The above model supports five supply chain functions: the reliability of delivery of goods, responsibility, flexibility, supply chain costs and asset management efficiency. Table 2 shows summarizes the definitions.

Table 2

The performance characteristics of the supply chain

\begin{tabular}{|c|c|c|}
\hline Row & Index Name & Definition \\
\hline 1 & Reliability & $\begin{array}{l}\text { Supply chain performance is appropriate for proper delivery, at the right time, to the appropriate } \\
\text { location, availability and packaging, in appropriate quantity and volume, with appropriate } \\
\text { documentation and customer. }\end{array}$ \\
\hline 2 & Responsibility & The supply chain speed in delivering products to the customer. \\
\hline 3 & Flexibility & Supply chain agility in response to market changes to gain or maintain competitive advantage \\
\hline 4 & Cost & Costs related to supply chain operations \\
\hline 5 & Efficiency & $\begin{array}{l}\text { The effectiveness of an organization in managing assets and property in order to support the demand } \\
\text { response, It includes all types of assets, including fixed assets and circulation assets }\end{array}$ \\
\hline
\end{tabular}

In this study, we use the following variables defined by the SCOR model to measure the dependence between the performance metrics of the supply chain performance and financial success of the firm.

Market Value $(Y)$ is measured as the number of common shares issued per year multiply by stock price at the end of financial year. $X_{1}$ is the revenue which is a criterion for reliability, responsiveness and flexibility. Our first measure of supply chain is an increase in revenue, which is an indicator of the characteristics of reliability, the responsiveness and the mobility of the supply chain. A key component of successful management involves the integration of downstream customers with high suppliers' 
management. In the supply chain, each trading unit, as a customer, is a supplier for the next year. Increasing revenue means that companies can be able to deliver good products and services that are the product of effective use of supply chain may satisfy their customers' satisfaction. A higher increase means that the organization has been more successful in managing its supply chain and customer satisfaction. Therefore, we expect revenue to be positively associated with the financial success of the company. The next independent variable $\left(\mathrm{X}_{3}\right)$ is the cash to cash cycle time which is an index for the property management attribute of the supply chain. Here, Cash cycle time $=$ period collection periodliabilities period + reporting period. The cash-to-critique cycle focuses as a wide scale used in the supply chain representing how assets are being used in the capital. This index can be achieved through the combination of claims collection period, liabilities period and equity duration period. The retention period is obtained by dividing the value of assets and finished selling, and on average indicates the length of inventory turnover. The collection period of receivables receivable divided by accounts receivable is calculated and represents the median time between sales and receipt. The period of payment of debts by dividing accounts payable on the finished products of the sold goods is a measure of how long the company takes to settle with its suppliers. The cash-to-cash cycle is expected to be negatively correlated with financial success. Effective supply chain management, while reducing stock levels, reduces the storage space and cash flow (Seuring, 2006). Finally, the last independent variable, $\left(X_{4}\right)$ represents the return on working capital which is an indicator of the property management attribute in the supply chain. Efficiency net working capital is calculated by net working capital divided by earnings before interest tax dividend and amortization (EBITDA). At the end, a criterion is used in relation to the return on investment (ROI), which is obtained by dividing the profit margin on the cash flow. While there are many metrics such as margins, operating profit or net profit to measure interest, we prefer to use the EBITDA. The net working capital is also equal to the amount invested in the accounts receivable and stock in hand receivable minus accounts payable. We expect that the return on working capital in circulation is positively associated with the financial success of the company.

The present study uses the information of the companies listed in Borsa Istanbul (BIST) investigated for a period of six years, i.e. 2012-2017, eligible based on different criteria. First, the firm must be accepted before 2012 and all the required information must be available over the period 2012-2017, i.e. the period of the study. There must be no change in fiscal year of the firm over the period 2012-2017. The selected firms are from the manufacturing companies and finally, all required information must be available.

\section{The results}

In this section, each of the hypotheses is tested in order to determine the impact on the test procedures.

\subsection{The correlation between financial success and supply chain practices}

The $t$ test with independent samples has been used to examine the first four hypotheses. The $t$ test is used with the independent samples when the researchers have intended to examine a characteristic between the two groups. In this stage of research, companies based on sales growth, finished cost, cash recycling cycle and capital return on their circulation have been divided into two upper and lower portfolios. On the other hand, the top companies in the first portfolio and low average companies are classified into the second portfolio and then, using the t-test with independent samples, we have investigated whether or not there is a significant difference between the two portfolios in terms of financial success.

The first hypothesis investigates whether there is a significant difference between financial success of the firms with high sales growth and low sales growth. The survey yields a t-student value of 2.045(Sig. $=0.043$ ) where the degree of freedom is 187 and the mean difference is 0.57 . This means that, there is a significant difference between the mean of high-growth companies and low-growth companies. Thus the first hypothesis is accepted when the level of significance is five percent. 
The second hypothesis investigates whether there is a significant difference between the financial success of high prime cost companies and low prime cost companies. The survey yields a t-student value of 0.965 (Sig. $=0.337$ ) where the degree of freedom is 134 and the mean difference is 0.44 . Obviously, there is not a significant difference between the financial success of high prime cost companies and low prime cost companies. Thus the second hypothesis is not accepted when the level of significance is five or even ten percent.

The third hypothesis tries to find out whether or not there is a significant difference between financial success of firms with shorter cash recycling cycle and firms with higher cash recycling cycle. The survey yields a t-student value of -2.364 (Sig. $=0.364$ ) where the degree of freedom is 157 and the mean difference is 0.79 . Accordingly, there is not a significant difference between financial success of the firms with shorter cash recycling cycle and firms with higher cash recycling cycle. Therefore, the third hypothesis is not accepted when the level of significance is five or even ten percent.

Finally, the last hypothesis of the survey attempts to determine whether there is a significant difference between financial success of the firms with high productivity rates and the ones with low productivity rates. The t-student value is equal to -3.261 (Sig. $=0.035)$ where the degree of freedom is 154 and the mean difference is 0.64 . This means that, there is a significant difference between financial success of the firms with high productivity rates and the ones with low productivity rates. Thus the fourth hypothesis is accepted when the level of significance is five percent.

\subsection{Testing the scale of the effect of SCM criteria on financial success}

To examine the scale of the effect of SCM criteria on financial success, we have used the regression model presented by Eq. (1) and test the following hypothesis,

$\mathrm{H}_{5}$ : Investors consider the supply chain components in their assessments when evaluating the stock.

The result of the regression estimated is given in Eq. (2). As we can observe, the result of DurbinWatson is in the range of $1.5-2.5$, which indicates of the absence autocorrelation, on the other hand, $\mathrm{F}$ -fisher test on a significant level supports $99 \%$ of the regression fitting, so according to these two statistics, the results of the regression are acceptable. Also, the statistics of the Adjusted- $\mathrm{R}^{2}$ indicates independent variables could describe approximately $36 \%$ of the changes of the dependent variable. Similarly, the results obtained for the sales growth variables and return rates indicate that there was a positive and significant relationship between these variables and the firm value. At the same time, the results obtained for the cost variable and the cash recycling cycle are not significant and our sample does not provide results confirming this relationship.

$$
\begin{array}{lccccc}
Y_{i}= & 0.086+0.283 x_{1 i}-0.014 x_{2 i}-0.057 x_{3 i}+0.117 x_{4 i}+\varepsilon_{i} \\
\text { t-value } & 0.64 & 2.46 & 2.65 & 4.03 & 1.17 \\
\text { p-value } & 0.5 & 0.01 & 0.24 & 0.37 & 0.03
\end{array}
$$

$$
\text { Adjust } \mathrm{R}^{2}=0.368 \text { F-Statistics }=11.37(0.00) \text { D.W. }=2.46
$$

\section{Conclusion}

This study was an attempt to find a possible relationship between the effective management of SCM practices and their financial success. As mentioned earlier, the study has tried to answer the following questions:

R1: Are companies with good supply chain performance financially successful?

R2: Which of the four SCM criteria mentioned in this paper preserves more effect on financial success? 
The results of the research hypotheses in response to the first part have indicated that the market value of the firms with high sales growth maintained a significant difference with companies with low sales growth. Likewise, compared with the companies with high investment returns and considering the portfolio of the firms with low investment returns, the results of the study have indicated that there was a significant difference between the mean of high-growth companies and low-growth ones.

Results also show that, among the variables investigated only the sales growth variable and the return rate have maintained positive and significant effects on market value. In addition, the results have shown that the revenue and the return of capital were positively correlated with the capital market value while the prime cost was represented as a percentage of revenue and cash to cash circle. The results are consistent with findings of Grant et al. (1988), Gunasekaran et al. (2004) and Ogbeide and Akanji (2018).

Out of four criteria for valuing SC, only revenue $\left(X_{1}\right)$ has provided the greatest impact on the prediction of financial success. The other variables; namely prime cost of a percentage of revenue $\left(X_{2}\right)$, cash to cash circle $\left(X_{3}\right)$ and return on working capital $\left(X_{4}\right)$ have appeared to play a negligible effects on predicting the financial success, which indicates that income as an index for the reliability, responsibility and flexibility of the supply chain was an important factor for managers when designing and developing company strategies.

\section{Acknowledgement}

The authors would like to thank the anonymous referees for constructive comments on earlier version of this paper.

\section{References}

Arifin, M., Ibrahim, A \& Nur, M. (2019). Integration of supply chain management and tourism: An empirical study from the hotel industry of Indonesia. Management Science Letters, 9(2), 261-270.

Aitken, J., Childerhouse, P., \& Towill, D. (2003). The impact of product life cycle on supply chain strategy. International Journal of Production Economics, 85(2), 127-140.

Asiyanbi, H., \& Ishola, A. (2018). E-banking services impact and customer satisfaction in selected bank branches in Ibadan metropolis, Oyo state, Nigeria. Accounting, 4(4), 153-160.

Ballou, R. H., Gilbert, S. M., \& Mukherjee, A. (2000). New managerial challenges from supply chain opportunities. Industrial Marketing Management, 29(1), 7-18.

Barge, P., Gay, P., Merlino, V., \& Tortia, C. (2013). Radio frequency identification technologies for livestock management and meat supply chain traceability. Canadian Journal of Animal Science, 93(1), 23-33.

Beamon, B. M. (1999). Measuring supply chain performance. International Journal of Operations \& Production Management, 19(3), 275-292.

Broz, D., Rossit, D., Rossit, D \& Cavallin, C. (2018). The Argentinian forest sector: opportunities and challenges in supply chain management. Uncertain Supply Chain Management, 6(4), 375-392.

Burgess, K., Singh, P. J., \& Koroglu, R. (2006). Supply chain management: a structured literature review and implications for future research. International Journal of Operations \& Production Management, 26(7), 703-729.

Cachon, G., \& Fisher, M. (1997). Campbell soup's continuous replenishment program: evaluation and enhanced inventory decision rules. Production and Operations Management, 6(3), 266-276.

Cao, M., \& Zhang, Q. (2011). Supply chain collaboration: Impact on collaborative advantage and firm performance. Journal of Operations Management, 29(3), 163-180.

Carter, C. R., \& Liane Easton, P. (2011). Sustainable supply chain management: evolution and future directions. International Journal of Physical Distribution \& Logistics Management, 41(1), 46-62.

Chan, F. T., Qi, H. J., Chan, H., Lau, H. C., \& Ip, R. W. (2003). A conceptual model of performance measurement for supply chains. Management Decision, 41(7), 635-642. 
Charvet, F. F., Cooper, M. C., \& Gardner, J. T. (2008). The intellectual structure of supply chain management: A bibliometric approach. Journal of Business Logistics, 29(1), 47-73.

Chen, I. J., \& Paulraj, A. (2004). Towards a theory of supply chain management: the constructs and measurements. Journal of Operations Management, 22(2), 119-150.

Chopra, S., \& Meindl, P. (2007). Supply chain management. Strategy, planning \& operation. In Das summa summarum des management (pp. 265-275). Gabler.

Christopher, M. (1998). Logistics and supply chain management: strategies for reducing cost and improving service. London. Financial times.

Cooper, M. C., Lambert, D. M., \& Pagh, J. D. (1997). Supply chain management: more than a new name for logistics. The International Journal of Logistics Management, 8(1), 1-14.

Davis, S. (2005). Showing C-level executives from CEOs to COOs the ways to find value in logistics and supply chain management. Logistics Quarterly, 2(2), 1-30.

Dugato, M., Favarin, S., \& Camerini, D. (2015). Estimating the counterfeit markets in Europe. TRANSCRIME RESEARCH IN BRIEF

Gardner, R., \& Lambert, D. (2006). The role of subject associations. Geography, 91, 159-171.

Ellram, L. M., \& Cooper, M. C. (1990). Supply chain management, partnership, and the shipper-third party relationship. The International Journal of Logistics Management, 1(2), 1-10.

Erhun, F., Keskinocak, P., \& Tayur, S. (2008). Dynamic procurement, quantity discounts, and supply chain efficiency. Production and Operations Management, 17(5), 543-550.

Fisher, M., Hammond, J., Obermeyer, W., \& Raman, A. (1997). Configuring a supply chain to reduce the cost of demand uncertainty. Production and Operations Management, 6(3), 211-225.

Frohlich, M. T., \& Westbrook, R. (2002). Demand chain management in manufacturing and services: web-based integration, drivers and performance. Journal of Operations Management, 20(6), 729745.

Grant, R. M., Jammine, A. P., \& Thomas, H. (1988). Diversity, diversification, and profitability among British manufacturing companies, 1972-1984. Academy of Management Journal, 31(4), 771-801.

Gunasekaran, A., Patel, C., \& McGaughey, R. E. (2004). A framework for supply chain performance measurement. International Journal of Production Economics, 87(3), 333-347.

Hartley, J. L., \& Choi, T. Y. (1996). Supplier development: customers as a catalyst of process change. Business Horizons, 39(4), 37-44.

Holland, J., Seely, J., \& Leland, H. (2006). U.S. Patent Application No. 11/151,855.

Huang, X., Kristal, M. M., \& Schroeder, R. G. (2008). Linking learning and effective process implementation to mass customization capability. Journal of Operations Management, 26(6), 714729.

Kaya, E., \& Azaltun, M. (2012). Role of information systems in supply chain management and its application on five-star hotels in Istanbul. Journal of Hospitality and Tourism Technology, 3(2), 138-146.

Ketzenberg, M. E., Van Der Laan, E., \& Teunter, R. H. (2006). Value of information in closed loop supply chains. Production and Operations Management, 15(3), 393-406.

Krause, D. R., Vachon, S., \& Klassen, R. D. (2009). Special topic forum on sustainable supply chain management: introduction and reflections on the role of purchasing management. Journal of Supply Chain Management, 45(4), 18-25.

Lai, K. H., Ngai, E. W. T., \& Cheng, T. C. E. (2002). Measures for evaluating supply chain performance in transport logistics. Transportation Research Part E: Logistics and Transportation Review, 38(6), 439-456.

Lambert, D. M., García-Dastugue, S. J., \& Croxton, K. L. (2005). An evaluation of process-oriented supply chain management frameworks. Journal of Business Logistics, 26(1), 25-51.

New, S., \& Ramsay, J. (1997). A critical appraisal of aspects of the lean chain approach. European Journal of Purchasing \& Supply Management, 3(2), 93-102.

Ogbeide, S \& Akanji, B. (2018). Stock market development and economic growth of Brazil, Russia, India, China and South African (BRICS) Nations: An empirical research. Accounting, 4(2), 83-92. 
Otto, A., \& Kotzab, H. (2003). Does supply chain management really pay? Six perspectives to measure the performance of managing a supply chain. European Journal of Operational Research, 144(2), 306-320.

Pettit, T. J., Fiksel, J., \& Croxton, K. L. (2010). Ensuring supply chain resilience: development of a conceptual framework. Journal of Business Logistics, 31(1), 1-21.

Scott, C., \& Westbrook, R. (1991). New strategic tools for supply chain management. International Journal of Physical Distribution \& Logistics Management, 21(1), 23-33.

Spekman, R. E. (1991). US buyers' relationships with Pacific Rim sellers. International Journal of Purchasing and Materials Management, 27(1), 2-10.

Stewart, G. (1997). Supply-chain operations reference model (SCOR): the first cross-industry framework for integrated supply-chain management. Logistics Information Management, 10(2), 6267.

Thomas, R. W., Clifford Defee, C., Randall, W. S., \& Williams, B. (2011). Assessing the managerial relevance of contemporary supply chain management research. International Journal of Physical Distribution \& Logistics Management, 41(7), 655-667.

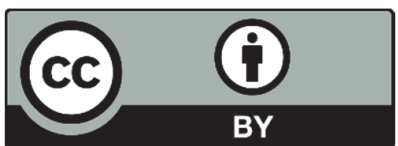

(C) 2019 by the authors; licensee Growing Science, Canada. This is an open access article distributed under the terms and conditions of the Creative Commons Attribution (CC-BY) license (http://creativecommons.org/licenses/by/4.0/). 